\title{
IMPLEMENTASI KURIKULUM 2013 DI SMK NEGERI 1 KAHAYAN HILIR KABUPATEN PULANG PISAU
}

\author{
Dewiyati \\ SMK Negeri 1 Kahayan Hilir Kabupaten Pulang Pisau \\ Jln. Mantaren I, Kahayan Hilir, Kabupaten Pulang Pisau, Kalimantan Tengah \\ e-mail:carlodewi@gmail.com
}

\begin{abstract}
This study aimed to describe implementations, the obstacles and drivers of implementations, and an alternative model to the implementation of the Curriculum 2013 at SMK Negeri 1 Kahayan Hilir Pulang Pisau Regency. This research was conducted by using field research. Data collection techniques were interviews and documentation. Data analysis technique was qualitative descriptive data analysis techniques. The results of the study show that: (1) the implementations of Curriculum 2013 were related to the use of KTSP which is limited without being able to develop further according to science and technology. (2) the limited professional educators who impact on the imbalance between general teaching and character; and (3) the quality curriculum was only able to achieve $60 \%$ required that textbooks and supporting all field-based studies curriculum in accordance with the previously applied.
\end{abstract}

Keywords: implementation, curriculum 2013, vocational high school (SMK)

\begin{abstract}
Abstrak: Penelitian ini bertujuan untuk mendeskripsikan implementasi, penghambat dan pendorong implementasi, dan model alternatif implementasi Kurikulum 2013 di SMK Negeri 1 Kahayan Hilir Kabupaten Pulang Pisau. Penelitian ini dilakukan dengan menggunakan penelitian lapangan. Teknik pengumpulan data dilakukan dengan wawancara dan dokumentasi. Teknik analisis data adalah deskriptif kualitatif. Hasil penelitian menunjukan bahwa: (1) implementasi kurikulum 2013 terkait dengan penggunaan KTSP yang terbatas tanpa mampu mengembangkan lebih jauh lagi sesuai tuntutan IPTEK; (2) terbatasnya tenaga pendidik yang profesional yang berdampak pada ketidakseimbangan antara antara pengajaran umum dan karakter; dan (3) mutu kurikulum yang hanya mampu dicapai $60 \%$ yang disyaratkan yakni buku-buku wajib dan penunjang semua bidang studi berbasis kurikulum sesuai dengan yang telah diterapkan.
\end{abstract}

Kata Kunci: implementasi, kurikulum 2013, sekolah menengah kejuruan (SMK)

\section{Latar Belakang}

Kurikulum 2013 adalah sebuah kuriku-

lum baru yang dibuat oleh pemerintah untuk memajukan pendidikan di Indonesia. Banyak wacana pro dan kontra dalam pelaksanaan kurikulum 2013. Dalam sebuah media ada yang menyatakan pelaksanaan kurikulum 2013 dianggap prematur karena kesiapan sekolah dan guru yang masih minim. Namun, tidak sedikit yang mendukung kurikulum 2013 cepat terlaksana.

Di Kabupaten Pulang Pisau Provinsi Kalimantan Tengah mulai semester ganjil ta- hun ajaran 2014/2015 kurikulum 2013 sudah dilakukan di semua Sekolah Menengah Kejuruan (SMK). Berdasarkan keputusan Menteri Pendidikan sekolah yang baru menerapkan kurikulum 2013 satu semester diminta untuk kembali menggunakan kurikulum 2006 (KTSP), sedangkan sekolah yang sudah tiga semester menerapkan kurikulum 2013 diminta untuk menjadi sekolah percontohan. Salah satu SMK yang diwajibkan melaksanakan kurikulum 2013 dan dijadikan sekolah percontohan adalah SMK Negeri 1 Kahayan Hilir Kabupaten Pulang Pisau. 
Berdasarkan hasil observasi sementara yang dilakukan di SMK Negeri 1 Kahayan Hilir Kabupaten Pulang Pisau terdapat beberapa permasalahan yang ditemukan dalam pelaksanaan kurikulum 2013 seperti belum optimalnya kesiapan sekolah dalam mengimplementasikan kurikulum 2013. Guru masih kerepotan dalam penerapan metode pembelajaran saintifik, sedangkan guru yang menguasai TIK $\pm 60 \%$. Sarana dan prasarana sekolah yang ada belum sesuai untuk membantu keberhasilan pelaksanaan kurikulum, seperti perangkat TIK yang masih kurang. Selain itu, kesiapan dan kinerja guru dalam menerapkan kurikulum 2013 terkendala oleh buku-buku yang terlambat datang. Guru masih kesulitan dalam pelaksanaan penilaian berdasarkan kurikulum 2013 dikarenakan format penilaian yang lebih rumit dan penguasaan TIK guru yang masihlemah.

Kurikulum 2013 diberlakukan mulai tahun ajaran 2013/2014, di mana dalam kenyataan di lapangan masih menemui banyak masalah antara lain masalah terkait sosialisasi dan pelatihan guru tentang kurikulum 2013, masalah terkait kesiapan guru/tenaga kependidikan, masalah terkait kesiapan fasilitas sekolah/sarana prasarana, dan masalah terkait bagaimana pelaksanaan kurikulum 2013. Meskipun perencanaan pembelajaran sebagian besar terlaksana, tetapi untuk sosialisasi kurikulum 2013 di mata pelajaran kelompok produktif belum ada dan silabus kurikulum 2013 untuk sebagian besar mata pelajaran kelompok produktif belum tersedia. Pembelajaran adalah proses interaksi antar peserta didik, antara peserta didik dengan tenaga pendidik dan sumber belajar pada suatu lingkungan belajar (Permendikbud No. 103 Tahun 2014). Kenyataan yang ada sekarang ini masih terdapat guru yang tidak siap dalam merencanakan maupun melaksanakan kurikulum 2013.

Permasalahan yang dikemukakan pada identifikasi masalah tidak dapat dibahas semuanya dalam penelitian ini karena berbagai faktor dan keterbatasan peneliti. Agar pembahasan dapat lebih terfokus dan mendalam permasalahan dalam penelitian ini dibatasi pada kesiapan guru dalam mengimplementasikan kurikulum 2013. Secara garis besar kesiapan guru dalam mengimplementasikan ku- rikulum 2013 meliputi perencanaan proses pembelajaran, pelaksanaan proses pembelajaran, dan penilaian proses pembelajaran. Ketiganya merupakan komponen yang saling terkait dan menentukan tingkat keberhasilan pelaksanaan kurikulum 2013, sehingga diperlukan suatu penelitian terhadap kesiapan guru dalam mengimplementasikan Kurikulum 2013.

Dengan memperhatikan latar belakang, identifikasi masalah dan batasan masalah maka permasalahan dalam penelitian ini dapat dirumuskan sebagai berikut ini.

1. Bagaimana implementasi kurikulum 2013 di SMK Negeri 1 Kahayan Hilir Kabupaten Pulang Pisau?

2. Apa yang menjadi penghambat dan pendorong implementasi kurikulum 2013 di SMK Negeri 1 Kahayan Hilir Kabupaten Pulang Pisau?

3. Bagaimana model alternatif dengan implementasi kurikulum 2013 di SMK Negeri 1 Kahayan Hilir Kabupaten Pulang Pisau?

\section{Kajian Literatur}

Mazmanian dan Sabatier dalam Wahab (2011:65) menjelaskan bahwa implementasi kebijakan adalah memahami apa yang senyatanya terjadi sesudah program dinyatakan berlaku atau dirumuskan. Fokus perhatian implementasi kebijakan, yaitu kejadian-kejadian atau kegiatan yang timbul setelah disahkannya pedomanpedoman kebijakan negara, yaitu mencakup baik usaha-usaha untuk mengadministrasikannya maupun untuk menimbulkan akibat/dampak nyata pada masyarakat atau kejadian-kejadian. Edward III (1980) menjelaskan bahwa studi implementasi kebijakan adalah krusial bagi public administration dan public policy. Implementasi kebijakan adalah tahap pembuatan kebijakan antara pembentukan kebijakan dan konsekuensi-konsekuensi kebijakan bagi masyarakat yang dipengaruhinya.

Senada dengan model implementasi kebijakan yang dikemukakan oleh Edwards III, menurut Van Meter dan Van Horn (1975) ada enam variabel yang mempengaruhi kinerja implementasi kebijakan yaitu (1) standar dan sasaran kebijakan, (2) sumber daya, (3) komunikasi antar organisasi, (4) karakteristik agen pelaksana, (5) kondisi sosial, eko- 
nomi dan politik dan (6) disposisi. Menurut Edward III (1980) faktor pertama yang mempengaruhi implementasi adalah komunikasi. Keputusan-keputusan kebijakan dan perintah-perintah harus diteruskan kepada personil yang tepat sebelum keputusan-keputusan dan perintah-perintah itu dapat diikuti. Tentu saja komunikasi harus akurat dan harus dimengerti dengan cermat oleh para pelaksana.

Kurikulum dipandang sebagai suatu rencana yang disusun untuk melancarkan proses belajar-mengajar di bawah bimbingan dan tanggung jawab sekolah beserta staf pengajarnya (Nasution, 2009:5). Berdasarkan Undang-Undang Nomor 20 Tahun 2003 tentang Sistem Pendidikan Nasional Pasal $1 \mathrm{Bu}$ tir 19, kurikulum adalah seperangkat rencana dan pengaturan mengenai tujuan, isi, dan bahan pelajaran serta cara yang digunakan sebagai pedoman penyelenggaraan kegiatan pembelajaran untuk mencapai tujuan pendidikan tertentu. Menurut Surahmad dalam Nurgiyantoro (2010:6), kurikulum didefinisikan sebagai suatu program pendidikan yang direncanakan dan dilaksanakan untuk mencapai sejumlah tujuan pendidikan tertentu. Manajemen kurikulum adalah sebagai suatu sistem pengelolaan kurikulum yang kooperatif, komprehensif, sistemik, dan sistematik dalam rangka mewujudkan ketercapaian tujuan kurikulum (Rusman, 2010: 3).

Menurut Rusman (2010:75), untuk mengimplementasikan kurikulum sesuai dengan rancangan, dibutuhkan beberapa kesiapan, terutama kesiapan pelaksana. Sebagus apapun desain atau rancangan kurikulum yang dimiliki, keberhasilannya sangat tergantung terhadap guru. Kurikulum yang sederhanapun apabila gurunya memiliki kemampuan, semangat, dan dedikasi yang tinggi, hasilnya akan lebih baikdari desain kurikulum yang hebat, tetapi kemampuan, semangat dan dedikasi gurunya rendah. Guru adalah kunci utama keberhasilan implementasi kurikulum. Sumber daya pendidikan yang lainpun seperti sarana prasarana, biaya, organisasi, lingkungan, juga merupakan kunci keberhasilan pendidikan, tetapi kunci utamanya adalah guru. Dengan sarana, prasarana, dan biaya terbatas, guru yang kreatif dan berdedikasi tinggi, dapat mengembangkan program, kegiatan, dan alat bantu pembelajaran yang ino- vatif.

Menurut Mulyasa (2013:6-7), kurikulum 2013 adalah kurikulum yang berbasis kompetensi sekaligus berbasis karakter (competency and character based curriculum), yang dapat membekali peserta didik dengan berbagai sikap dan kemampuan yang sesuai dengan tuntutan perkembangan zaman dan tuntutan teknologi. Melalui pengembangan Kurikulum 2013 yang berbasis karakter dan kompetensi, kita berharap bangsa ini menjadi bangsa yang bermartabat, dan masyarakatnya memiliki nilai tambah (added value), dan nilai jual yang bias ditawarkan kepada orang lain dan bangsa lain di dunia, sehingga kita bisa bersaing, bersanding, bahkan bertanding dengan bangsa-bangsa lain dalam percaturan global. Hal ini dimungkinkan, kalau implementasi Kurikulum 2013 betul-betul dapat menghasilkan insan yang produktif, kreatif, inovatif, dan berkarakter.

Pendidikan karakter dalam kurikulum 2013 bertujuan untuk meningkatkan mutu proses dan hasil pendidikan, yang mengarah pada pembentukan budi pekerti dan akhlak mulia peserta didik secara utuh, terpadu, dan seimbang, sesuai standar kompetensi lulusan pada setiap satuan pendidikan. Melalui implementasi kurikulum 2013 yang berbasis kompetensi sekaligus berkarakter, dengan pendekatan tematik dan kontekstual diharapkan peserta didik mampu secara mandiri meningkatkan dan menggunakan pengetahuannya, mengkaji dan menginternalisasi serta mempersonilisasi nilai-nilai karakter dan akhlak mulia sehingga terwujud dalam perilaku sehari-hari.

\section{Metode Penelitian}

Penelitian ini dilakukan dengan menggunakan penelitian lapangan (case study research and field study research). Untuk teknik pengumpulan data dilakukan dengan cara membagikan wawancara dan dokumentasi. Teknik analisis data adalah proses pengaturan dan pelacakan secara sistematis semua transkrip wawancara, catatan lapangan dan materi-materi lainnya yang telah ditulis peneliti selama proses pengumpulan data dengan menggunakan teknik analisis data deskriptif kualitatif. 


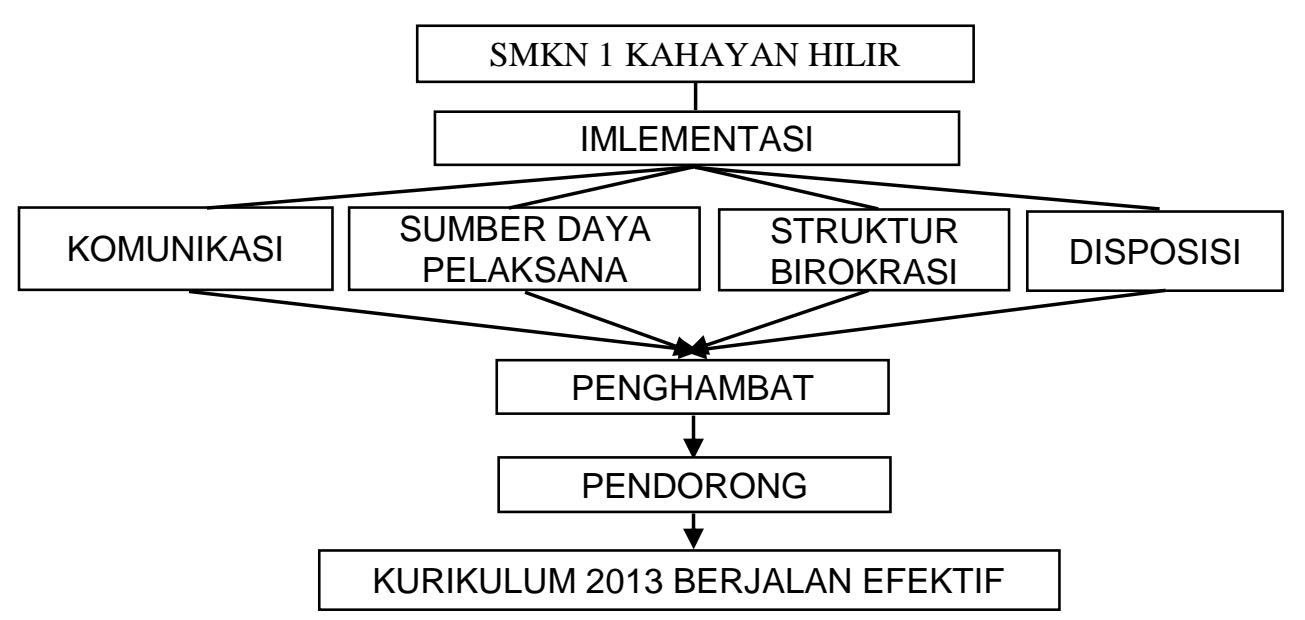

Gambar 1: Kerangka Pikir Penelitian

\section{Hasil Penelitian dan Pembahasan}

Dalam subpoin ini peneliti membahas terkait hasil penelitian mengenai implementasi kebijakan kurikulum 2013 pada SMKN 1 Kahayan Hilir Kabupaten Pulang Pisau dengan menyesuaikannya dengan teori-teori yang berada di dalam literatur model implementasi Edward III.

Kejelasan ukuran dan tujuan kebi-jakan dengan demikian perlu dikomunikasi-kan secara tepat dengan para pelaksana. Konsistensi atau keseragaman dari ukuran dasar dan tujuan perlu dikomunikasikan sehingga pelaksana mengetahui secara tepat ukuran maupun tujuan kebijakan itu. Komunikasi dalam organisasi merupakan suatu proses yang amat kompleks dan rumit. Di samping itu sumber informasi yang berbeda juga akan melahirkan interpretasi yang berbeda pula Agar implementasi berjalan efektif, siapa yang bertanggungjawab melaksanakan sebuah keputusan harus mengetahui apakah mereka dapat melakukannya. Sesungguhnya implementasi kebijakan harus diterima oleh semua pelaksana dan harus mengerti secara jelas dan akurat mengenai maksud dan tujuan kebijakan. Jika para implemetor kebijakan bingung dengan apa yang akan mereka lakukan dan jika dipaksakan maka tidak akan mendapatkan hasil yang optimal. Tidak cukupnya komunikasi kepada para implementor secara serius mempengaruhi implementasi kebijakan. Pada pembahasan mengenai hasil dalam faktor komunikasi yang terjadi pada implementasi kebijakan kurikulum 2013.
Pada pembahasan mengenai hasil dalam faktor sumber daya yang terdapat dalam implementasi kebijakan kurikulum 2013 pada SMKN 1 Kahayan Hilir Kabupaten Pulang Pisau, peneliti juga akan menjabarkan ke dalam dua indikator yang terdapat dalam faktor sumber daya. Dua indikator tersebut antara lain: implementasi kebijakan tidak akan berhasil tanpa adanya dukungan dari sumber daya manusia yang cukup kualitas dan kuantitasnya. Kualitas sumber daya manusia berkaitan dengan keterampilan, dedikasi, profesionalitas, dan kompetensi di bidangnya, sedangkan kuantitas berkaitan dengan jumlah sumber daya manusia apakah sudah cukup untuk melingkupi seluruh kelompok sasaran. Sumber daya manusia sangat berpengaruh terhadap keberhasilan implementasi, sebab tanpa sumber daya manusia yang handal implementasi kebijakan akan berjalan lambat. Oleh karena itu, implementasi kebijakan Kurikulum 2013 di SMKN 1 Kahayan Hilir Kabupaten Pulang Pisau membutuhkan sumber daya yang cukup dan mampu untuk menguasai dibidangnya dalam melaksanakan kebijakan tersebut. Sumber daya manusia (staff) yang dimaksud dalam pelaksanaan kebijakan kurikulum 2013 adalah guru yang merupakan sebagai seorang pendidik, pembimbing, dan mediator pada proses pembelajaran. Guru adalah ujung tombak keberhasilan perubahan sebuah kurikulum. Maka guru harus memiliki kesiapan yang memadai dan matang, mulai dari kesiapan dari segi kualifikasi, kompetensi serta juga siap dalam hal 
kesamaan pemahaman dan paradigma (pola pikir) terhadap kurikulum baru tersebut. Guru SMKN 1 Kahayan Hilir Kabupaten Pulang Pisau merupakan guru yang sudah memiliki kualitas dan kuantitas memadai dari tingkat pendidikan tinggi minimal S1, professional dan kompetensi di bidangnya. Guru di sini mendapatkan tugas berat dalam pemahaman dan pengimplementasian kurikulum 2013 ini di sekolah. Merubah mindset guru dalam mengajar dan memberikan penilaian yang berupa perindividu untuk siswa dinilai sulit dilakukan oleh pihak guru. Maka hal ini dibutuhkan Skill dan keterampilan yang dituntut kepada setiap guru agar dapat lebih kreatif dan lebih berinovasi dalam kegiatan proses belajar di sekolah. Pelatihan yang diadakan oleh Dinas Pendidikan seharusnya dapat lebih mempercepat dan memahami sistem yang ada di kurikulum 2013.

Berdasarkan penjelasan di atas, dapat disimpulkan bahwa sumber daya merupakan faktor penting demi terselenggaranya kebijakan dengan baik di mana dalam pelaksanaannya guru harus memiliki kesiapan yang memadai dan matang, mulai dari kesiapan dari segi kualifikasi, kompetensi serta juga siap dalam hal pemahaman dan paradigma (pola pikir) terhadap kurikulum baru tersebut. Pemerintah Kabupaten Pulang Pisau harus mengupayakan agar perubahan kurikulum ini menjadi jembatan dalam memperbaiki sistem pendidikan SMKN 1 Kahayan Hilir Kabupaten Pulang Pisau. Terlebih dalam membantu guru dalam merubah pola ajar yang kuno dan menciptakan karakter-karakter positif dalam diri siswa, sehingga tidak hanya menciptakan siswa yang pintar secara akademik tapi juga cerdas dalam berperilaku.

Perintah-perintah implementasi cenderung tidak efektif apabila dalam implementasi kurikulum 2013 kekurangan sumber daya pendukung, salah satu sumber penting adalah fasilitas atau sarana prasarana seperti bahan ajar dan alat praktek yang digunakan dalam proses belajar di kelas. sarana prasarana pendidikan menjadi salah satu hal penting dalam menjamin mutu layanan penyelenggaraan kegiatan belajar mengajar di sekolah. Oleh karena itu saran prasarana harus secara tepat disiapkan pada saat akan dipergunakan. Berdasarkan hasil penelitian, diketahui bahwa sara- na dan prasarana dalam proses pelaksanaan kebijakan kurikulum 2013 di SMK N 1 Kahayan Hilir Kabupaten Pulang Pisau belum terpenuhi dengan baik. Hal ini disebabkan karena terhambatnya pendistribusian buku ajar dan buku panduan guru yang disiapkan oleh pemerintah pusat, sehingga dinas pendidikan menghimbau kepada setiap sekolah yang melaksanakan kurikulum 2013 untuk berusaha dalam memfasilitasi pelaksanaan itu sendiri seperti mendownlod buku ajar dan buku panduan guru. Menurut Edward III, sumber daya nonmanusia berupa sarana prasarana merupakan hal yang penting dalam implementasi. Apabila seseorang pelaksana memiliki staff yang memadai, memahami apa yang harus dilakukan, tetapi tanpa adanya sarana prasarana yang mendukung maka implementasi yang dilaksanakan tidak akan berhasil karena kekurangan sarana prasarana yang dibutuhkan akan menghambat implementasi kebijakan yang efektif. Selain bahan ajar, sumber daya non-manusia juga mencakup sarana dan prasarana yang tersedia di sekolah untuk menunjang pembelajaran kurikulum 2013. Berdasarkan hasil penelitian diketahui bahwa sarana prasarana yang ada di SMK Negeri 1 Kahayan Hilir Kabupaten Pulang Pisau sudah lengkap, hanya saja dari sisi jumlah belum sebanding antara fasilitas yang tersedia dengan jumlah siswa yang ada.

Berdasarkan penjelasan di atas, sarana prasarana pendidikan merupakan salah satu hal penting dalam menjamin mutu layanan penyelenggaraan kegiatan belajar mengajar di sekolah. Oleh karena itu sarana prasarana harus secara tepat disiapkan pada saat akan dipergunakan. Dalam hal ini pelaksanaan kurikulum 2013 belum dapat dikatakan berjalan sesuai dengan harapan, karena sarana prasarana yang dibutuhkan sekolah dalam kegiatan belajar mengajar belum semua terpenuhi, sehingga hal ini belum sesuai dengan apa yang dikemukakan oleh Edward III yang menyatakan bahwa sumber daya non-manusia berupa sarana prasarana merupakan hal yang penting dalam implementasi.

Salah satu faktor yang mempengaruhi implementasi kebijakan adalah sikap implementor. Kecenderungan perilaku atau karakteristik dari pelaksana kebijakan berperan penting untuk mewujudkan implementasi ke- 
bijakan yang sesuai dengan tujuan atau sasaran. Karakter penting yang harus dimiliki oleh pelaksana kebijakan misalnya kejujuran dan komitmen yang tinggi. Berdasarkan data hasil penelitian dapat diamati dari pernyataan informan yang menyatakan bahwa sikap pelaksanaan dalam implementasi kebijakan kurikulum 2013 di SMKN 1 Kahayan Hilir Kabupaten Pulang Pisau cukup baik. Pelaksana kebijakan dalam hal ini selalu siap untuk melaksanakan kebijakan Kurikulum 2013 untuk membangun pendidikan SMKN 1 Kahayan Hilir Kabupaten Pulang Pisau.

Dinas pendidikan selaku perpanjang tangan dari Kementrian Pendidikan dan Kebudayaan bekerjasama dengan LPMP selalu siap mendukung sepenuhnya pelaksanaan kebijakan Kurikulum 2013. Kurikulum ini merupakan kurikulum pengganti KTSP yang dilakukan pemerintah dengan niatan untuk memperbaiki sistem pendidikan. Dalam hal ini agar pelaksanaan kebijakan kurikulum 2013 berjalan seperti yang diharapkan, sesuai dengan intruksi dari pusat Dinas Pendidikan bertanggunjawab mempersiapkan kepala sekolah dan guru untuk memahami dan melaksanakan Kurikulum 2013 pada tingkat satuan pendidikan dan menyebarluaskan informasi pelaksanaan Kurikulum 2103 kepada instansi terkait serta melaksanakan pembinaan atau pelatihan yang bekerjasama dengan LPMP kepada sekolah yang melaksanakan kurikulum 2013.

Adanya perubahan kurikulum ini pihak sekolah dan guru-guru yang melaksanakan kurikulum 2013 pun menyambut dengan antusias seperti mengikuti dengan antusias segala kegiatan yang diselenggarakan oleh pemerintah yang berhubungan dengan tercapainya pelaksanaan kurikulum 2013 dan dengan cekatan guru menerapkan apa yang sudah mereka pahami dari pelatihan yang mereka dapatkan. Antusias terhadap pelaksanaan kurikulum 2013 juga dapat dilihat dari komitmen guru sebagai mediator siswa di sekolah menjadi lebih berinovasi dan bertanggung jawab dalam pelaksanaan Kurikulum 2013 di SMKN 1 Kahayan Hilir Kabupaten Pulang Pisau.

Namun, permasalahan yang terjadi sampai saat ini menimbulkan pertanyaan yang besar tentang kebijakan kurikulum 2013 yang kurangnya perencanaan yang matang. Sebaiknya, implementasi kurikulum 2013 dilaksanakan setelah tercapainya kesiapan dan kompetensi guru-guru di sekolah. Kesiapan guru sangat penting dalam pengimplementasian kurikulum 2013, karena guru sebagai penentu keberhasilan kurikulum 2013 yang diharapkan bisa menyiapkan dan membuka diri terhadap berbagai kemungkinan terjadinya perubahan. Maka dari itu, perlu adanya persiapan yang matang dari pemerintah dalam setiap sistem yang diperlukan untuk pelaksanaan kurikulum2013.

Berdasarkan hal di atas, peneliti menyimpulkan jika para implementor bersikap baik terhadap suatu kebijakan tertentu, dalam hal ini berarti adanya dukungan, kemungkinan besar mereka melaksanakan kebijakan sebagaimana yang diinginkan oleh pembuat kebijakan. Demikian pula apabila tingkah laku atau perspektif-perspektif para pelaksana berbeda dengan para pembuat keputusan, maka proses pelaksanaan suatu kebijakan menjadi semakin sulit. Namun ketika suatu kebijakan diterapkan maka harus adanya perencanaan yang matang dari pembuat kebijakan dan harus serius menyikapi permsalahan yang menjadi hambatan pelaksanaan Kurikulum 2013. Karena Implikasi yang akan terjadi dalam implementasi kebijakan kurikulum 2013 ke depannya. Jika hal tersebut dibiarkan, akan menjadi sebuah tradisi aparat pelaksana yang tidak baik dan menyebabkan ketidakpercayaan masyarakat terhadap pelaksana kebijakan.

Pada pembahasan mengenai hasil dalam faktor struktur birokrasi yang terdapat pada kebijakan kurikulum 2013 pada SMKN 1 Kahayan Hilir Kabupaten Pulang Pisau. Kurikulum 2013 ini merupakan kebijakan yang mesti direncanakan dengan matang karena kurikulum 2013 ini akan dilaksanakan di seluruh Indonesia. Pelaksanaan suatu kebijakan akan dapat berjalan dengan baik apabila adanya standar operasi prosedur sebagai pedoman pelaksanaan kebijakan yang telah dibuat agar berjalan dengan sistematis. Pelaksanaan kebijakan kurikulum 2013 pada SMKN 1 Kahayan Hilir Kabupaten Pulang Pisau telah diatur dalam prosedur-prosedur dasar kerja atau standar operational prosedur (SOP). 
Dari hasil penelitian dapat diketahui bahwa dalam pelaksanaan kebijakan kurikulum 2013 pada SMKN 1 Kahayan Hilir Kabupaten Pulang Pisau telah diatur prosedurprosedur dasar pelaksanaan, prosedur-prosedur dasar kerja atau SOP sangat dibutuhkan dalam pelaksanaan suatu kebijakan. Prosedur-prosedur dasar kerja adalah prosedurprosedur atau standar yang dijadikan acuan dalam pelaksanaan suatu kebijakan. Dengan adanya prosedur-prosedur dasar kerja maka implementasi kebijakan dapat sesuai dengan rencana yang telah ditetapkan sebelumnya. Hal ini sesuai dengan yang dikemukan oleh Edward III yang mengatakan bahwa dengan menggunakan SOP para pelaksana dapat memanfaatkan waktu yang tersedia dan menyeragamkan tindakan-tindakan dari pejabat di dalam organisasi. Lengkapnya SOP tentang pelaksanaan kebijakan Kurikulum 2013 di SMKN 1 Kahayan Hilir Kabupaten Pulang Pisau, struktur birokrasi sudah tersedia dari mulai level yang paling tinggi yaitu provinsi hingga ke level yang paling rendah yaitu daerah. Ketersediaan kelembagaan ini menjadikan setiap lembaga yang ditunjuk memiliki tugas dan wewenang masing-masing dalam melaksanakan kebijakan kurikulum 2013, karena dengan adanya kejelasan tugas dan beban kerja dari setiap instansi memberikan kemudahan bagi instansi lainnya dalam mengerjakan tugasnya serta tindakan-tindakan pejabat jadi lebih konsisten.

Berdasarkan hasil penelitian pada subpoin hasil penelitian, dapat diamati bahwa terkait fragmentasi dalam implementasi kebijakan kurikulum 2013 di SMKN 1 Kahayan Hilir Kabupaten Pulang Pisau telah berjalan baik. Pada pelaksanaannya, peneliti mengamati berjalannya implementasi kebijakan kurikulum 2013 di SMKN 1 Kahayan Hilir Kabupaten Pulang Pisau ini telah terjalin koordinasi antar pelaksana Kebijakan kurikulum 2013 di SMKN 1 Kahayan Hilir Kabupaten Pulang Pisau yaitu melalui kerjasama antara Dinas Pendidikan, LPMP dan sekolah SMKN 1 Kahayan Hilir Kabupaten Pulang Pisau. Melalui kerjasama atau koordinasi yang baik dalam pelakasanaan masing-masing tugas, dinas pendidikan sebagai perpanjangan tangan dari pemerintah pusat yang bertanggungjawab untuk mempersiapkan ke- pala sekolah dan guru dalam memahami dan melaksanakan kurikulum 2013 pada tingkat satuan pendidikan dan menyebarluaskan informasi pelaksanaan kurikulum 2103 kepada instansi terkait serta melaksanakan Pembinaan atau pelatihan yang bekerjasama dengan LPMP ke sekolah-sekolah yang melaksanakan kurikulum 2013.Maka fragmentasi yang terjadi sesuai dengan ungkapan Edward III yang mengatakan bahwa fragmentasi adalah pembagian tanggung jawab sebuah bidang kepada unit-unit organisasi. Fragmentasi yang dilakukan Dinas Pendidikan, LPMP dan sekolah SMKN 1 Kahayan Hilir Kabupa-ten Pulang Pisau dalam implementasi kebi-jakan Kurikulum 2013 akan terus berjalan efektif ketika pelaksanaan kebijakan tersebut dijalankan dengan penyebaran tanggung jawab yang baik. Dari pejelasan di atas dapat disimpulkan bahwa dalam pelaksanaan kebijakan Kurikulum 2013 pada SMK 1 Kahayan Hilir Kabupaten Pulang Pisau pelaksana kebijakan yang telah ditetapkan oleh pemerintah pusat. Pembagian peran dimaksudkan untuk mempermudah pelaksanaan kebijakan ini, walaupun masing-masing aparat pelaksana kebijakan mempunyai tugas dan tanggung jawab yang berbeda-beda, tetap diperlukan koordinasi antara aparat pelaksana kebijakan.

\section{Kesimpulan}

Kesimpulan dalam penelitian ini adalah sebagai berikut ini.

1. Kurikulum 2013 di SMKN 1 Kahayan Hilir Kabupaten Pulang Pisau terkait dengan penggunaan KTSP yang terbatas tanpa mampu mengembangkan lebih jauh lagi sesuai tunututan IPTEK. Silabus yang digunakan hanya sesuai petunjuk yang telah baku, tanpa dikembangkan dengan menggunakan kurikulum lain yang dapat dijadikan bahan perbandingan. Dalam mekanisme kerja untuk menentukan rencana pembelajaran (RP) antara guru dan kepala sekolah terjalin kerjasama yang baik, sehingga RP yang disusun sesuai dengan tujuan yang terdapat dalam kurikulum.

2. Penghambat dan pendorong implementasi kurikulum 2013 di SMKN 1 Kahayan Hilir Kabupaten Pulang Pisau menyangkut keterbatasnya tenaga pendidik yang profesional sehingga dalam proses belajar 
mengajar selalu terjadi ketidakseimbangan antara antara pengajaran umum dan karakter. Proses belajar mengajar di kelas yang hanya mengandalkan keaktifan guru tanpa ada metode pengajaran yang digunakan berupa metode ceramah, metode tanya jawab, dan metode diskusi.

3. Model alternatif dengan implementasi kurikulum 2013 di SMK Negeri 1 Kahayan Hilir Kabupaten Pulang Pisau terkait dengan mutu kurikulum yang hanya mampu dicapai $60 \%$ yang disyaratkan yakni bukubuku wajib dan penunjang semua bidang studi berbasis kurikulum sesuai dengan yang telah diterapkan yakni mengembangkan lebih jauh lagi sesuai tunututan IPTEK. Pengetahuan guru kenyataannya di sekolah ini belum mampu mencapai standar mengingat kurikulum yang digunakan terbatas pada isi yang baku tanpa mampu mengembangkannya secara kompetitif sebagaimana yang seharusnya dicapai yakni adanya inovasi dan pemgembangan isi secara luas.

Berdasarkan permasalahan-permasalahan yang ditemukakan maka disarankan hal-hal sebagai berikut ini.

1. Bagi kepala sekolah untuk lebih meningkatkan mutu pendi-dikan kepala sekolah sebaiknya mela-kukan pembinaan dalam bentuk on the job training untuk semua personil se-kolah yaitu: pimpinan dan guru-guru agar masing-masing dapat selalu meningkatkan kualitas kerjanya. Kepala sekolah sebaiknya dapat terus membuka peluang kerjasama dengan pihak luar yang dapat dijadikan sebagai pendukung mutu Pendidikan sehingga mampu memberikan kontribusi secara material maupun fasilitas penunjang kegiatan belajar-mengajar guna mendukung berhasilnya penerapan sistem manajemen mutu.

2. Bagi guru hendaknya kerjasama tim dan semangat kerja yang telah ada untuk ditingkatkan guna mewujudkan kualitas sekolah yang unggul. Guru sebaiknya bersedia mengikuti program pelatihan penerapan Sistem manajemen mutu yang dilaksanakan oleh pimpinan sekolah maupun pihak luar, agar pengetahuan guru-guru mengenai pentingnya penerapan sistem manajemen mutu bagi eksistensi sebuah sekolah dapat bertambah, sehingga keterampilan guru dalam menerapkan manajemen mutu juga dapat lebih meningkat.

3. Bagi dinas pendidikan kabupaten agar meningkatkan kualitas sebuah sekolah merupakan salah satu langkah yang tepat untuk dikembangkan di se-buah sekolah. Oleh karena itu sosialisasi mengenai metode yang diadopsi dari lingkungan industri ini sebaiknya diperkenalkan juga di lingkungan pendidikan. Dinas pendidikan Kabupaten juga diharapkan aktif berperan serta dalam memberi-kan dukungan terhadap sekolah yang menerapkan perbaikan mutu pendidik-an melalui sistem manajemen kuriku-lum sesuai dengan prosedur yang ber-laku.

\section{DAFTAR PUSTAKA}

Edward III George C., 1980, Implementing Public Policy, Congressional Quarterly Press, Washington DC :

Mulyasa A., 2013, Pengembangan dan Implementasi Kurikulum 2013, Remaja Rosdakarya, Bandung.

Nasution S., 2009, Kurikulum dan Pengajaran, Bumi Aksara, Jakarta.

Nurgiyantoro Burhan, 2010, Dasar-Dasar Pengembangan Kurikulum, BPFE Yogyakarta.

Rusman, 2010, Manajemen Kurikulum. Rajawali Pers Raja Grafindo Persada, Jakarta.

Republik Indonesia, Permendikbud No. 103 Tahun 2014 tentang Pedoman Pelaksanaan Pembelajaran, Kementrian Pendidikan dan Kebudayaan, Jakarta.

Republik Indonesia, Undang-Undang No. 20 Tahun 2003 tentang Sistem Pendidikan Nasional, Kementrian Pendidikan dan Kebudayaan, Jakarta.

Van Meter, Donald dan Van Horn, Carl E., 1975, The Policy Implemention Process - A Conceptual Framework, Journal Administration and Society.

Wahab Abdul Aziz, 2011, Pendidikan Kewarganegaraan, Alfabeta, Bandung. 